\title{
交通混雑を考慮した観測リンク交通量から のOD交通量推計モデル
}

\author{
楊 海 ${ }^{*} \cdot$ 朝倉康夫 ${ }^{* *}$. 飯田恭敬 ${ }^{* * *}$. \\ 佐佐木綱 ${ }^{* * * *}$
}

\begin{abstract}
本研究では観測リンク交通量から交通混雑を考慮した OD 交通量推計モデルを提案 する. 具体的には, 従来の一般化最小二乗法による推計モデルから出発し, ネットワー ク均衡問題を制約条件とする推計モデルに展開・拡張し, 利用者の経路選択率を内生化 した OD交通量推計モデルを提案する. またモデルの数值解法を示すとともに, 簡単な 数值計算例を用いてその妥当性を明らかにする.

Keywords : O-D matrices, traffic counts, bilevel programming, user equilibrium
\end{abstract}

\section{1.はじめに}

観測リンク交通量を用いて OD 交通量を推計するモ デルがこれまでに数多く提案されている. その代表的な モデルとしてはエントロピー最大化 ${ }^{11,2)}$, 最尤推定

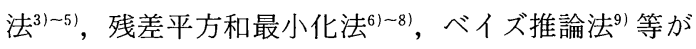
ある.この分野の研究成果については, 飯田・高山 ${ }^{10)}$,

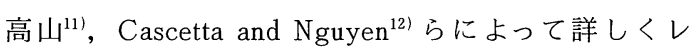
ビューされている.これらのモデルは一般に式（1）の ように表すことができる.

$\min F_{1}(t, \bar{t})+F_{2}(v, \bar{v})$

subject to

$$
v=M(t)
$$

ここに, $\bar{t}=\left[\cdots, \bar{t}_{w}, \cdots\right]^{T}:$ ターゲット OD 交通量ベク トル, $\bar{t}_{w}: \mathrm{OD}$ ペア $w \in W$ 間の交通量, $W: \mathrm{OD}$ ペア集 合;

$\bar{v}=\left[\cdots, \bar{v}_{a}, \cdots\right]^{T}$ : 観測リンク交通量ベクトル, $\bar{v}_{a}:$ リンク $a \in \bar{A}$ 上の観測交通量, $\bar{A}$ : 観測リンク集合;

$t, v:$ それぞれ推計すべき OD 交通量べクトルとそれ に基づく配分リンク交通量ベクトル；

$F_{1}(t, \bar{t}), F_{2}(v, \bar{v}):$ それぞれべクトル $t, \bar{t}$ および $v$, $\bar{v}$ 間の一般化距離あるいは誤差を表す関数（例えば，工 ントロピー距離関数 ${ }^{21}$, ユークリッド距離関数 $\left.{ }^{6)}\right)$ ：

$v=M(t)$ は $t$ を $v$ に写像する関数であり, 交通混雑を 考えるか否かによって特定の配分原則に依存する.

交通混雑による利用者経路選択への影響が小さい場 合, flow-independent な多経路比例配分モデル (例えば, Dial 確率配分モデル ${ }^{23)}$ ) が利用され, 式 (2) は次のよ

\footnotetext{
*学生会員 工修 京都大学大学院博士課程 ( (606 京都市左京区吉田本町)

**正会員 工博 愛媛大学助教授 工学部土木工学教室

*** 正会員 工博 京都大学教授 工学部交通土木工学教室

****正会員 工博 京都大学教授 工学研究科環境地球工学専 攻
}

うに特定化できる.

$$
v=P t \text {. }
$$

ここで, $P=\left[p_{w}^{a}\right]$ は配分比例行列といい, その要素 $p_{w}^{a}(a$ $\in \bar{A}, w \in W)$ はOD ペア $w$ 間の交通量がリンク $a$ を利 用する割合を表す.

$v=P t$ が利用者の経路選択を正確に反映しており, ま た観測交通量誤差がない場合, 配分リンク交通量を観測 リンク交通量に一致させ, $F_{2}(v, \bar{v})=0$ とすることが考 えられる. よって, 次のタイプのモデルが得られる. $\min F_{1}(t, \bar{t})$

subject to

$$
P t=\bar{v}
$$

従来の推計モデルの多くは式（1)，（3）で示す線形 比例配分に基づくモデルタイプ，あるいは式（4)，(5) で示す確定的方程式を制約条件とするモデルタイプに属 している.

Flow-independent な比例配分を用いる場合, 推計モ デルはシングルな凸計画問題として定式化され, 数学的 に容易に解くことができる. 特にモデルの統計的性質を 解析的に求められるという利点がある ${ }^{61,71,12) ~ 14) . ~}$

しかしながら, Flow-independent な交通量配分に基 づく推計モデルには経路選択率の整合性に問題が残され ている.すなわち, 固定的に与えた経路選択率を用いて 観測リンク交通量から OD 交通量を推計するのに対し, OD 交通量は常に利用者均衡配分によってネットワーク に割り当てられている. このため利用者均衡配分で得ら れる経路選択率はOD 交通量推計において先決した経 路選択率と異なろう. さらに, 経路選択率を固定値とし た等式制約条件（5）は, 交通量の観測誤差と配分比例 行列を特定化する際に生じる誤差等によって実行可能解 を持たない場合もあるため, 観測交通量デー夕等に対し て事前処理を施す必要がある2),15).

このような問題点を解決するために, ネットワーク均 
衡をOD 交通量推計過程に取り込み, 利用者の経路選 択率を内生的に決定するいくつかの方法が提案された.

Erlander et $\mathrm{al}^{37)}$, Fisk and Boyce ${ }^{38)}$ は観測交通量デー 夕を用いて分布・配分統合モデルのパラメータを推定す ることにより，OD 交通量を求める手法を提案した．河 上ら ${ }^{39)}$ はFisk and Boyce のモデル ${ }^{38)}$ を拡張し, 分布・ 分担・配分統合モデルという形で交通手段別 OD 交通 量を推定している. また赤松・高木 ${ }^{40)}$ は需要変動型利 用者均衡モデルを逆解析し, 均衡 OD コストとOD 交 通量を同時推定するモデルを提案した．たたし，前者の 方法では観測リンクフローに含まれる情報をトータルコ ストに集計化した形で扱っているため, ODパターンの 分布およびトータル発生・集中交通量に関する情報を追 加する必要がある. また後者の方法では OD ペアごと に需要関数を設定しており, 需要関数の設定方法に問題 が残ると言える ${ }^{8)}$.

Nguyen $^{(6)}$ は均衡交通量配分を行ったときのリンク交 通量が観測リンク交通量に一致するように OD 交通量 を求めるモデルを提案した. ただし，Nguyen のモデル では，OD 交通量が一意的に定まらないため，OD 交通 量の選択基準を表す第二の目的関数を追加する必要があ る ${ }^{17)}$. また楊・佐佐木 ${ }^{18)}$ は, Nguyenのモデルと同じ前 提条件のもとで, OD 交通量がより簡単な方法で求めら れることを示している.

Fisk ${ }^{19), 20)}$ は, Willumsenのエントロピー最大化によ る OD 交通量推計モデル 2 を交通混雑が存在する場合に 拡張し, 観測リンク交通量と利用者均衡問題を制約条件 とする推計モデルを提案した.

Fiskのモデルにおいては, 観測リンク交通量が利用 者均衡条件を満足するものとして, 確定的制約条件とし てモデルに組込まれている. またNguyen のモデルでは, OD 間の所要時間を計算するためにすべてのリンクに対 する観測データを必要としている.しかし実際には，こ れらの条件を満たすことは非常に難しいであろう.

現実のネットワークにおいては, 交通量の不規則変動 および観測誤差等によって，リンク交通量の観測データ はフロー保存条件を満足しない場合がありうる. また観 測データはフロー保存条件を満たしても, 利用者均衡条 件を満足するとは限らない(18),21),221. そうした場合, Fisk のモデルにおいては実行可能解は存在しない. ま た Nguyen のモデルでは配分リンク交通量が観測リンク 交通量に一致するような OD 交通量を求めることはで きない(18). したがって，これらのモデルを実際に応用す るためには，まず交通量の観測デー夕に対する事前処理 を実施しなければならない.しかしこれまでの研究では, 誤差を含んだ観測データからフロー保存条件を満たすよ うなリンク交通量を求めるいくつかの有効な方法が提案 されたものの ${ }^{21,15)}$, 観測リンク交通量が利用者均衡条件
を満たすか否か, また満足しなければ，如何に観測デー 夕から均衡条件を満たすようなリンク交通量を求めるか については, 大きな課題として残っている ${ }^{18)}$.

したがって本研究では, 交通混雑を考慮した, 観測り ンク交通量からの新たな OD 交通量推計モデルを提案 する. 具体的には利用者均衡条件をモデルに取り入れ, ターゲット OD 交通量と観測リンク交通量データのラ ンダム特性, すなわち誤差を考慮したモデルを目指す. この目的を達成するために, flow-independentな交通 量配分に基づく式（1）（３）で示す推計モデルを, 利 用者均衡問題を制約条件とする推計モデルに展開・拡張 する. その結果として推計モデルは 2 レベル計画問題と して定式化される. 上位問題は式 (1) で示す一般化距 離あるいは誤差を最小にし，下位問題は通常の利用者均 衡問題である. またモデルの数值解法を提示するととも に, 従来の 2 レベル計画問題を解くための方法との区別 を明らかにする. 最後に簡単な計算例を用いて, 数値解 法の妥当性を説明する.

\section{OD 交通量推計の 2 レベル最適化モデル}

ここでは，まず従来の一般化最小二乗法 (generalized least squares：GLS）による推計モデルを混雑するネッ トワークの場合に適用できることを示す. GLS 法の持 つ特徴の一つは, 観測リンク交通量データとOD 交通 量データの信頼性に応じてそれらを統合し, 同一の目的 関数に組み込むことができる点にある ${ }^{6), 71,11,12) .}$

ターゲット OD 交通量 $\bar{t}_{w}, w \in W$ が $\mathrm{OD}$ サンプル調查 あるいは重力モデル等によって推計されているとする.

$\mathrm{OD}$ 交通量 $\bar{t}$ とリンク交通量 $\bar{v}$ を確率変数として, 真実 $\mathrm{OD}$ 交通量 $t$ と配分リンク交通量 $v$ に関する次の関係式

$$
\begin{aligned}
& \bar{t}=t+\zeta \cdot \\
& \bar{v}=v+\eta
\end{aligned}
$$

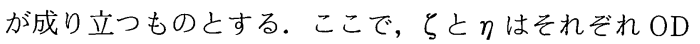
サンプル調査と交通量観測データの誤差を表すランダム ベクトル変数であり, $E(\zeta)=0, E(\eta)=0$ とする場合が 多( $\left.\left.{ }^{6)}, 7\right), 12\right)$.

タイプ（1）に属する GLS 推計モデルは推計 OD 交 通量とターゲットOD 交通量, また配分リンク交通量 と観測リンク交通量との二乗残差加重平方和を最小にす るように定式化される ${ }^{6}$.

GLS :

$$
\min _{t}(\bar{t}-t)^{T} U^{-1}(\bar{t}-t)+(\bar{v}-v)^{T} W^{-1}(\bar{v}-v)
$$

ここで， $U, W$ は加重マトリックスであり，一般にそ れぞれランダムベクトル $\zeta, \eta$ 分散・共分散マトリッ クスとして与えられている.

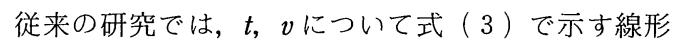
関係式を用いてきた ${ }^{6), 7), 12)}$. そのような flow-indepen- 
dent な交通量配分が利用者の経路選択を正確に表して おり，また $E(\zeta)=0, E(\eta)=0$ という仮定が成立すれば， 以上の GLS による推定量は真実 OD 交通量の最良線形 不偏推定量（best linear unbiased estimate）であるこ とを示すことができる61,12).

本研究では, 利用者の経路選択が利用者均衡原理に従 うものと仮定する.つまり各 OD ペア間の利用者は起 終点間の最短経路を選択し, 次の様な均衡関係を満足す る.

$$
\left[\begin{array}{l}
u_{r}=u_{w} \text { if } f_{r}>0 \\
u_{r} \geqq u_{w} \text { if } f_{r}=0
\end{array} \quad r \in R_{w}, \quad w \in W\right.
$$

ここで,

$$
\begin{aligned}
& f_{r}=\text { 経路 } r \text { の交通量 } \\
& u_{w}=\mathrm{OD} ヘ ゚ ア, w \in W \text { の最短経路時間 } \\
& u_{r}=\text { 経路 } r \in R \text { の所要時間 } \\
& u_{r}=\sum_{a \in A} c_{a}\left(v_{a}\right) \delta_{a r} \\
& \delta_{a r}=\left[\begin{array}{ll}
1 & \text { 経路 } r \text { がリンク } a \text { を通るとき } \\
0 & \text { そのほか }
\end{array}\right. \\
& A=\text { ネットワークのリンク集合 } \\
& R_{w}=\mathrm{OD} \text { ペア } w \text { 間の有効経路集合 } \\
& R=\left\{R_{w}: w \in W\right\}
\end{aligned}
$$

$c_{a}\left(v_{a}\right)=$ リンクコスト関数：リンク交通量に対して単調

\section{増加な連続関数とする.}

周知のように式（9）で示す利用者均衡 (userequilibrium : UE) 条件は次の非線形計画問題の最適性 条件と等価である ${ }^{23)}$.

$\mathrm{UE}$ :

$$
\lim _{v} \sum_{a \in A} \int_{0}^{v_{a}} c_{a}(x) d x
$$

subject to

$$
\begin{aligned}
& \sum_{r \in R w} f_{r}=t_{w} \quad w \in W \\
& f_{r} \geqq 0 \quad r \in R \cdots \cdots \cdots
\end{aligned}
$$

ここで,

$$
v_{a}=\sum_{r \in R} f_{r} \delta_{a r}
$$

したがって，以上で述べた GLS サブモデルとUEサ ブモデルを統合することにより，OD 交通量を推計する ための 2 レベル最適化モデル (bilevel optimization model : BOM) が得られる.

BOM :

$$
\min _{t}(\bar{t}-t)^{T} U^{-1}(\bar{t}-t)+(\bar{v}-v)^{T} W^{-1}(\bar{v}-v)
$$

subject to $t \geqq 0$

where $v$ solves

$$
\min _{v} \sum_{a \in A} \int_{0}^{V a} c_{a}(x) d x
$$

subject to

$$
\sum_{r \in R w} f_{r}=t_{w} \quad w \in W
$$

$f_{r} \geqq 0 \quad r \in R$

\section{3. モデルの説明}

ここに定式化したモデルは，次のような一般的な形で 表すことができる.

$$
\min _{t} F(t, v(t))
$$

subject to

$$
G(t, v(t)) \leqq 0
$$

where $v(t)$ is obtained by solving

$$
\min _{v} f(t, v)
$$

subject to

$$
g(t, v) \leqq 0
$$

この問題は上位決定変数 $t$ を持つ leader と下位決定 変数 $v$ をつ follower からなる Stackelberg 問題 ${ }^{36)}$ で あり, 次の特徴をもつことがわかる.

(1) 上位問題の目的関数 $F(t, v)$ は変数 $t$ 亡変数 $v$ に 関して狭義な凸関数である. また与えられた上位決定変 数 $t$ に対して, 下位問題の目的関数 $f$ はその決定変数 $v$ に関して狭義な凸関数である。さらに上・下位問題の制 約条件 $(G, g)$ も凸である. この様な問題を Bard は凸 2 レベル最適化問題と呼んでいる ${ }^{24)}$.

(2)この凸 2 レベル計画問題は実行可能解をもってい る。特に観測リンク交通量データがフロー保存条件ある いは利用者均衡条件を満足しなくても, 解の存在性は保 証できる.したがって，モデルの投入データに対する事 前処理を施す必要はない.

(3) ネットワークリンクの一部分で交通量が観測され ていればモデルは推計可能である（ただし，これまで記 述を簡潔にするために， $\bar{v} と v$ が同じ次元を持つ，つま り $\bar{A}=A$ として考えた, 一部のリンクのみで交通量が観 測され，つまり $\bar{A} \subset A$ の場合においては，式（8）ある いは式 (13) 第二項のリンク交通量に関する距離あるい は誤差は観測リンクのみに対して定義すれば良い)。ま た経路選択率は内生的に決定され, 求める OD 交通量 とリンク交通量は利用者均衡条件を満たす.

このように提案したモデルは種々の特徴をもっている が,一方, その解としての OD 交通量 $t$ の推計精度は夕一 ゲット OD 交通量 $\bar{t}$ の值に大きく依存するであろう。な ぜならば, $\bar{t}$ の大きさは上位問題の目的関数 $F_{1}(t, \bar{t})$, $F_{2}(v, \bar{v})$ の間にトレードオフを生じさせるからである. 従来の研究では, ターゲット OD 交通量は真実 OD 交 通量の不偏推計量 (式 $(6)$ の $E(\zeta)=0)$ であると仮 定しており，もしそれが成立すれば問題はないが，実際 にはその条件を満足しないことが多いであろう.すなわ ち, ターゲット OD 交通量 $\vec{t}$ は常に真実 OD 交通量 $t$ の 過小推計量 $(E(\zeta)<0)$ である.この過小推計は, 夕一 ゲットOD 交通量が過去に調査されたものであれば時 
間の経過に伴う総トリップ数の増加, 現時点の OD サ ンプル調査によるものであれば，調査漏れによる誤差な どと解釈することができる51,11),12). したがってこの場合, 観測リンク交通量からターゲット OD 交通量の更新が 期待できるものの，モデルは系統的なバイアスをもった 推計 OD 交通量を与えることになろう.

この問題を解決するために，上位問題の目的関数を置 き換えることが考えられる. 例えば, 式 $(8)$ で示すユ一 クリット距離関数の代わりに，次のようなエントロピー 距離関数を用いることが考えられる ${ }^{25)}$.

$$
\min _{t} \sum_{w \in W} t_{w}\left\{\log \left(\frac{t_{w}}{\bar{t}_{W}}\right)-1\right\}+r \sum_{a \in A} v_{a}\left\{\log \left(\frac{v_{a}}{\bar{v}_{a}}\right)-1\right\}
$$

このエントロピー目的関数は同様に $t, \bar{t}$ おび $v, \bar{v}$ 間の誤差を表すと解釈することができる ${ }^{25,26)}$. パラメ一 夕 $\gamma$ は OD 交通量データ $\bar{t}$ と観測交通量データ $\bar{v}$ の相対 的信頼度を反映する加重パラメータであり，その特定化 の方法についてはBrenninger-Gothe ら ${ }^{25)}$ によって詳し

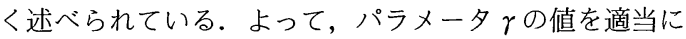
選べば，推計精度の向上が期待できよう.

以上のほかに種々の目的関数が考えられるが，ここで はトータル OD 交通量に関する制約条件を導入し，上 位問題の目的関数を修正することを考える ${ }^{10)}$.

まず既存ターゲット OD 交通量 $\bar{t}$ を用いて単位 OD 交 通量分布パターン $\bar{t}^{0}$ はつぎのように求められる.

$$
\bar{t}^{0}=\left[\cdots, \bar{t}_{w}^{0}, \cdots\right]^{T}, \quad \bar{t}_{w}^{0}=\frac{\bar{t}_{w}}{\sum_{w \in W} \bar{t}_{w}}
$$

$\bar{t}^{0}$ と推計すべき OD 交通量 $t$ を用いてターゲット OD 交通量 $\bar{t}$ を次のものとする.

$$
\bar{t}=\mu \bar{t}^{0}, \quad \mu=\sum_{w \in W} t_{w}
$$

ここで, $\mu$ は推計すべきトータル OD 交通量を表す変数 である。

$$
\begin{gathered}
\text { さらに, マトリックス } \\
H=\left[\begin{array}{cccc}
\bar{t}_{1}^{0} & \bar{t}_{1}^{0} & \cdots & \bar{t}_{1}^{0} \\
\bar{t}_{2}^{0} & \bar{t}_{2}^{0} & \cdots & \bar{t}_{2}^{0} \\
& \cdots & \cdots & \\
\bar{t}_{m}^{0} & \bar{t}_{m}^{0} & \cdots & \bar{t}_{m}^{0}
\end{array}\right] \cdots
\end{gathered}
$$

（ $m$ は OD ペア数を表す）を導入すると，トータル OD 交通量に関する制約条件を内生化するように，式 (8)で 示す目的関数は次のように修正される.

Modified BOM (MBOM) :

$$
\begin{aligned}
& \min F(t, v) \\
& =(H t-t)^{T} U^{-1}(H t-t)+(\bar{v}-v)^{T} W^{-1}(\bar{v}-v) \\
& =t^{T} G t+(\bar{v}-v)^{T} W^{-1}(\bar{v}-v)
\end{aligned}
$$

ここで, $G=(H-I)^{T} U^{-1}(H-I), I=$ 単位マトリックス.

この様な目的関数に対する修正は, 偏差のないあるい
は偏差の少ない OD 交通量を求めようとするものであ る.ただし, 推計に用いる分散・共分散マトリックス $U$, $W$ は推計精度にも影響するので, 如何に与えるかも重 要である．これらの情報が利用できない場合，単位マト リックス，またはターゲット OD 交通量, 観測リンク 交通量の既知値を対角線要素とする対角マトリックスと

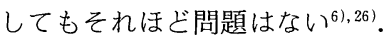

\section{4. 数 值解法}

Stackelberg 問題による定式化は交通計画分野におい てもすでに多くの研究がみられる27) 321. なかでも利用 者均衡制約下での最適ネットワーク形成問題を取り扱っ

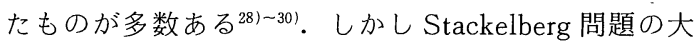
域的最適解を求めるための有効なアルゴリズムは存在し ないのが現状である ${ }^{24), 28), 32) . こ の た め ~ “ i n n e r-o u t e r ~}$ algorithm”あるいは “optimization-assignment algorithm”とよばれるヒューリスティックな方法が良く用い られてきた．本研究でも次に述べるヒューリスティック な解法を採用するが，その妥当性および従来のアルゴリ ズムとの区別を後ほど明らかにする.

基本的な考え方は上位問題と下位問題を繰り返して解 くことにより, 元の問題の解を得ようとする方法であり， 以下のように書くことができる.

Step 0. Initialize $P^{(0)}=\left[p_{w}^{a(0)}\right] ; k:=0$.

Step 1. Find $t^{(k+1)}$ using $P^{(k)}$.

Step 2. Determine $P^{(k+1)}=\left[p_{w}^{a(k+1)}\right]$ using $t^{(k+1)}$.

Step 3. Stopping criterion is met then stop; else let $k:=k+1$ and go to Step 1 .

Step 0 において初期值 $P^{(0)}$ は夕ーゲット OD 交通量 $\bar{t}$ をネットワークに配分することにより得られる.

Step 1 において OD 交通量は従来の方法で解析的に 求めることができる. 例えば, BOM の上位問題は通常 の最小二乗法問題となり, その解は次のように書くこと ができる6).

$$
t^{(k+1)}=\left(U^{-1}+P^{T(k)} W^{-1} P^{(k)}\right)^{-1}\left(U^{-1} \bar{t}+P^{T(k)} W^{-1} \bar{v}\right)
$$

また式 (26) で示す修正モデルの解は次のようになる.

$$
t^{(k+1)}=\left(G+P^{T(k)} W^{-1} P^{(k)}\right)^{-1} P^{T(k)} W^{-1} \bar{v}
$$

Step 2 において Frank-Wolfe 法とよばれる凸結合ア ルゴリズムを用いて各 OD 交通量をネットワークに配 分し, OD 交通量の経路利用率を求める.

Step 3 において OD 交通量 $t^{(k+1)}, t^{(k)}$ の相対変化率 を収束判断基準とする.つまり，

$$
\max _{W}\left|t_{w}^{(k+1)}-t_{w}^{(k)}\right| / t_{w}^{(k)} \leqq \varepsilon
$$

であるならば終了.ここで $\varepsilon は$ は啇当な小さな正数である.

この数值解法は $\mathrm{Hall}^{33)}$, Fisk ${ }^{19)}$ によって提案された 
アルゴリズムに基づくものであるが, Hall, Fisk は観 測リンク交通量を式 (5) で示すような確定的制約条件 (ただし $P$ は均衡配分によって求める) として OD 交 通量のエントロピー最大化モデルに取り入れたのに対 し, 本研究では観測リンク交通量を確率值として残差平 方和で示す目的関数に組み入れた点で上位問題の定式化 とその数值解法は異なる.

従来の 2 レベル最適化問題を解くためのヒューリス ティックな解法は上位問題と下位問題を切り離し, 下位 問題の決定変数を固定して上位問題を解くステップと, 上位問題の決定変数を固定して下位問題を解くステップ との交互的な反復解法である.このアルゴリズムは Cournot-Nash 均衡問題に忠実な解法となってはいるも のの, 下位問題を制約条件とするStackelberg 問題に最 適解を与えるとは限らないことが明らかにされてい る ${ }^{32), 34)}$. 本研究で用いるアルゴリズムでは, 上位問題と 下位問題を繰り返して解くという点で従来の “optimization-assignment algorithm”之共通であるが, それと 異なる一つの重要な点に注意すべきである.すなわち， 上位問題を解くたびに下位問題の決定変数 $v$ は固定して おらず, $v=P t$ (ただし $P$ は前回で求められたもの) と いう関係式をもって上位問題の決定変数 $t$ に従って変化 するという点である．このような応答関係は Stackelberg 問題の定式化のもつ leader-follower という関係を 明示的に考慮したことを意味している.

本アルゴリズムは事実上 descent-type であるような アルゴリズムとして次のように解釈することができる.

ネットワーク均衡問題に関する感度分析結果 ${ }^{+11} に よ$ り, 均衡フローパターンはOD交通量に対して連続的 に変化することから，以下ではリンク交通量（あるいは リンク利用率）の OD 交通量に対する微係数を用いて 説明をする（ただし，厳密に言えば，連続性が微分可能 性の充分条件ではないため, 劣微分を用いるべきであ る).

モデル BOM の上位問題の目的関数より

$$
\nabla_{t} F(t, v(t))=2(t-\bar{t})^{T} U^{-1}+2(v(t)-\bar{v})^{T} W^{-1} \nabla_{t} v(t)
$$

が容易に得られることはわかる. 均衡フロー $v(t)$ の OD 交通量 $t$ に対する微分は Tobin and Friesz ${ }^{35)}$ によっ て提案されたネットワーク均衡フローの感度分析方法を 用いて求めることができるが，それはやはり膨大な計算 量が必要である.ここではこれらの微分の近似值を求め ることを示そう。

$$
v(t)=P(t) t \text { or } v_{a}(t)=\sum_{w \in W} p_{w}^{a}(t) t_{w} \quad a \in \bar{A}
$$

より

$$
\frac{\partial v_{a}(t)}{\partial t_{w}}=p_{w}^{a}(t)+\sum_{w^{\prime} \in W} t_{w^{\prime}} \frac{\partial p_{w^{\prime}}^{a}(t)}{\partial t_{w}} .
$$

が得られる。また，

$$
\begin{aligned}
& z_{w}^{a}(t)=\sum_{w^{\prime} \in W} t_{w^{\prime}} \frac{\partial p_{w^{\prime}}^{a}(t)}{\partial t_{w}} \\
& Z(t)=\left[z_{w}^{a}(t)\right] \\
& \nabla_{t} v(t)=P(t)+Z(t) \\
& \nabla_{t} F(t, v(t))=2(t-\bar{t})^{T} U^{-1}+2(v(t)-\bar{v})^{T} W^{-1} P(t) \\
& +2(v(t)-\bar{v})^{T} W^{-1} Z(t)
\end{aligned}
$$

となることがわかる.

$p_{w}^{a}(t)$ の明示的な関数形は一般的にはわからないため, $Z(t)=\left[z_{w}^{a}(t)\right]$ の正確な数值を定めることはできない. つまり式 (35) 右辺の第三項は計算できない.しかし, 数值計算では, 目的関数全体の降下方向に着目すればよ <, 勾配 $\nabla_{t} F(t, v(t))$ の符号を変えずに近似值を求め れば良い。初期值とするターゲット OD 交通量が真実 $\mathrm{OD}$ 交通量に近ければ, 探索範囲は最適解の近傍にとど まり, $t_{w^{\prime}}\left(\partial p_{w^{\prime}}^{a}(t) / \partial t_{w}\right), w^{\prime} \in W$ は微小となる. したがっ て,この場合には, 式 (35) 右辺第三項, つまり $2(v(t)$ $-\bar{v})^{T} W^{-1} Z(T)$ が全体の降下方向決定に与える影響は 極めて小さく，計算上省略できる。また $p_{w}^{a}(t)$ そのも のは前回で得られた值で近似して良い。

結局, 数值アルゴリズムの各反復では次のような微分 近似值を用いることになる。

$$
\begin{aligned}
& \nabla_{t} v(t) \fallingdotseq p \\
& \nabla_{t} F(t, v(t)) \fallingdotseq 2(t-\bar{t})^{T} U^{-1}+2(P t-\bar{v})^{T} W^{-1} P
\end{aligned}
$$

ここで， $P$ は前回の計算で得られたものである.

数值計算の繰り返し操作では, $P(t)$ を前回求めた値 に固定して, 式 (37) で示す $\nabla_{t} F(t, v(t))$ をゼロとお いて OD 交通量 $t$ を求めている. このアルゴリズムが収 束するならば，収束点近傍では，OD 交通量の変化はほ とんどなく, 式 $(35)$ 右辺第三項 $2(v(t)-\bar{v})^{T} W^{-1} Z(t)$ はほぼゼロであり, 式 (37) を等号と考えてよい.つま り式 (37) の微分の近似值の収束点は $\nabla_{t} F(t, v(t))$ の 真実值に一致する.すなわち，

$$
\lim _{k \rightarrow \infty} \nabla_{t} F\left(t^{(k)}, v\left(t^{(k)}\right)\right) \rightarrow 0 \cdots
$$

ここで, リンクフローを OD 交通量の陰関数として考 えているので, 式 (14) で示す非負制約条件が非アクティ ブ (active) な制約条件であ机ば，最適解の必要条件は 式（38）がゼロになることである.したがって，このア ルゴリズムから最適 OD マトリックスが効率的に求め られると考えられる.

以上のように, 本研究で用いるアルゴリズムは従来の “optimization-assignment algorithm”と異なることは すでに明らかであろう，すなわち，従来のアルゴリズム では上位問題を解くたびに下位問題の決定変数を固定 


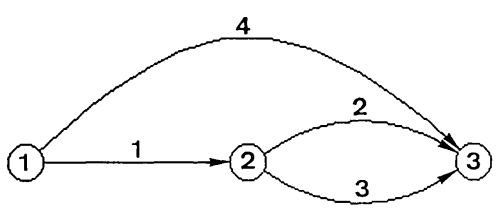

Fig.1 Test network.

Table 1 Data for test network.

\begin{tabular}{lll}
\hline $\begin{array}{l}\text { Link cost } \\
\text { function }\end{array}$ & $\begin{array}{c}\text { Target } 0-D \\
\text { matrix }\end{array}$ & $\begin{array}{c}\text { Observed 1ink } \\
\text { flows }\end{array}$ \\
\hline$c_{1}=20+v_{1}$ & $1 \rightarrow 3$ & $\bar{v}_{2}=25$ \\
$c_{2}=10+2 v_{2}$ & $\overline{\mathrm{t}}_{13}=30$ & $\overline{\mathrm{v}}_{3}=30$ \\
$\mathrm{c}_{3}=25+\mathrm{v}_{3}$ & $2 \rightarrow 3$ & $\overline{\mathrm{v}}_{4}=40$ \\
$\mathrm{c}_{4}=40+\mathrm{v}_{4}$ & $\overline{\mathrm{t}}_{23}=30$ & \\
\hline
\end{tabular}

$\left(\nabla_{t} v(t)=0\right)$ したため, Cournot-Nash 均衡解に収束す るが, Stackelberg 均衡解になるとは限らない.

一方，本アルゴリズムではリンク利用率 $P=\left[p_{w}^{a}\right]$ を 求めるために, ネットワークの経路フローパターンを求 める必要がある. しかし Wardrop 均衡問題ではリンク フローパターンは一意的に定まるが, 経路フローパター ンはそうではない231,35!. 提案したモデルにおいては上位 問題の目的関数が OD 交通量 $t$ とそれに対応するリンク フローパターン $v$ の関数として定義され，また与えら れる $t$ に対して $v$ が一意的に決まるため, 理論的には経 路フローパターンが一意的に決まらなくても, 問題の大 域的最適解は経路選択率によらないことが明らかであ る.しかしアルゴリズムの繰り返し計算過程では, 上位 問題を解くための経路選択率に関する情報が必要であ り, 均衡経路フローパターンの選択を行う必要がある.

本研究では一意的なリンクフローパターンを与える特 定の経路フローパターンを選ぶことにしている.すなわ ち, Frank-Wolfe 法を用いた交通量配分の繰り返し操 作で, 前後繰り返し計算における all-or-nothing 配分の 経路フローパターンを記録し，それをリンクフローパ ターンと同様に凸結合させる ${ }^{35)}$. したがって, 配分の終 了段階では各リンクフローの OD 内訳が記録され，OD 交通量ごとのリンク利用率が得られる．このような凸結 合法によって経路フローパターンを求めるとき, アルゴ リズムは極めて速やかに最適解に収束することが数值計 算実験によって確認されている.

\section{5. 数值計算実験}

以上で述べたヒューリスティックなアルゴリズムの妥 当性を数値的な面から確かめるために，簡単なネット ワークを用いた数値計算結果を紹介する. 用いたネット ワークはFig.1に示す 2 OD $(1 \rightarrow 3,2 \rightarrow 3), 4$ リンクか ら構成されるものである. リンクコスト関数, ターゲッ ト OD 交通量 $\bar{t}$ および観測リンク交通量 $\bar{v}$ は Table 1 に
Table 2 Numerical results for test network.

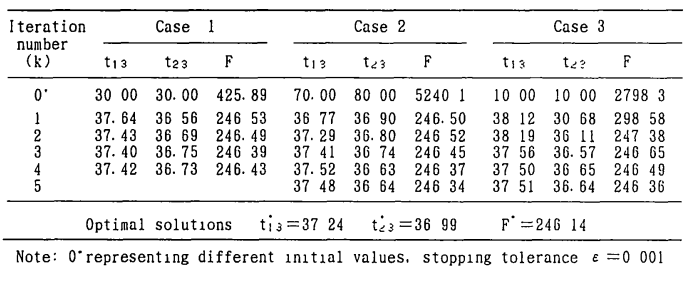

示されている.

リンク交通量の観測データとリンクコスト関数を用い てリンク 2 とリンク 3 の所要時間を計算するとそれぞれ $c_{2}\left(\bar{v}_{2}\right)=60, c_{3}\left(\bar{v}_{3}\right)=55$ が得られた. 明らかに観測誤差 等によって $c_{2}\left(\bar{v}_{2}\right) \neq c_{3}\left(\bar{v}_{3}\right)$ となるため, 均衡交通量配分 でこのようなリンクフローを生じるような OD マト リックスはありえない. したがって, 観測リンク交通量 を確定的制約条件とし，かつ利用者均衡をベースとした Fisk $^{19)}$, Nguyen ${ }^{16)}$ 等の推計モデルはこのネットワーク 例に適用できない. また本ネットワークでは部分リンク のみでフローが観測されているため, 全リンクフローの 観測値を必要とする推計モデルも適用できないことが明 らかである。

さて本研究で提案したモデル BOM を用いて OD 交 通量を求めてみよう. 簡単のために, 加重マトリックス $U, W$ をそれぞれ $(2 \times 2)$ と $(3 \times 3)$ の単位マトリッ クスとする. またこの計算例では, OD 交通量の最適解 は解析的に求めることができる.

Table 2 はアルゴリズムを用いて三つの異なる初期值 からの解の収束状況を示している. 明らかに提案した ヒューリスティックな解法は初期值によらず，4－5回 の繰り返しで解析的に求めた厳密解に収束することがわ かる.

以上のように簡単なネットワークを用いてアルゴリズ 厶の大域的収束性を確かめることができたが，モデルの 推計特性についてはさらに調べる必要がある.ただし， 提案したモデルは非線形 2 レベル最適化問題として定式 化されているため, その統計的性質を解析的に求めるこ とは非常に難しい. この点については，筆者らは数值シ ミュレーションによって, モデルの推計パフォーマンス について考察を行っている.これらの数值計算結果の詳 細については別の機会に報告する.

\section{6. おわりに}

本研究では交通混雑を考慮した観測リンク交通量から の OD 交通量推計モデルを提案した, 定式化した問題 は利用者均衡問題を制約条件としてもつ 2 レベル計画問 題である.

提案したモデルは交通混雑が利用者の経路選択に与え る影響, 観測リンク交通量およびターゲット OD 交通 
量に含まれるランダム誤差を明示的に考えたところで従 来の推計モデルと異なる.このような定式化の考え方は モデルに次のような特徴を持たせることになる. (1) 道 路網の一部リンクで交通量が観測されれば，OD 交通量 は推計可能である. (2) 利用者の経路選抓は均衡条件を 満足し，内生的に決定される。（3)観測リンク交通量が 誤差を含むまたは利用者均衡条件を満足しない場合にお いても，モデルは実行可能解を与える。

さらに問題を解くために，ヒューリスティックな繰り 返しによる解法を示し, 従来の 2 レベル問題を解くため の反復解法との区別を明らかにした。すなわち Stackelberg 問題のもつleader-follower という関係を本アルゴ リズムで明示的に考えた点である．また簡単な数值計算 例によって，ヒューリスティックな解法の大域的収束性 を確かめることができた.

したがって, 本モデルは交通混雑が経路選択に与える 影響が大きい，または観測リンク交通量とターゲット OD 交通量の投入データに誤差が含まれる場合に適用可 能なものであろう.

ただし，モデルの適用計算では膨大な計算量と記憶容 量が必要であるため，より効率的アルゴリズムの開発が 必要である. また実際規模のネットワークを用いた数值 的検証が必要である．異なる上位問題の目的関数を用い る場合，モデルの推計特性に関する相互比較分析も行う べきである.これらについては将来の研究課題としたい.

最後に, 本論文の作成にあたって, 京都大学工学部の 秋山孝正講師，川崎雅史助手に有益なご助言をいただき また本論文の査読委員の皆様から貴重なコメントをいた だいた。ここに記して深く謝意を表する次第である.

\section{参 考 文 献}

1）井上博司：スクリーンライン調查による OD 表の精度の 検定及び OD 表の修正法，交通工学，Vol.12，No.6, pp. 11 19, 1977.

2) Van Zuylen, J.H. and Willumsen, L.G. : The most likely trip matrix estimated from traffic counts, Transpn. Res. 14B, pp.281 293, 1980 .

3）井上博司：交通量調查資料を用いた OD 交通量の統計的 推計法, 土木学会論文報告集, No. 332, pp. 85 94, 1983.

4) Spiess, H. : A maximum likelihood model for estimating origin/destination matrices, Transpn. Res. 21B, pp.395 412, 1987.

5）飯田恭敬・高山純一：傾向変動を考慮したリンク交通量 による OD 交通量推計法, 土木学会論文集, No. 383/N-7, pp. 83 91, 1987.

6) Cascetta, E. : Estimation of trip matrices from traffic counts and survey data : A generalized least squares estimator, Transpn. Res, 18B, pp.289 299, 1984.

7) Bell, M.G.H. : The estimation of origin-destination matrices by constrained generalized least squares method, Transpn. Res, 25B, pp.13 22, 1991.
8）飯田恭敬・高山純一：リンクフロー観測值を用いた一重 制約型重力モデルによる OD 交通量推計法, 交通工学, Vol. 26, No. 1, pp. 27 39, 1991.

9) Maher, M.J. : Inferences on trip matrices from observations on link volumes : A Bayesian statistical approach, Transpn. Res. 17B, pp.435 447, 1983.

10）飯田恭敬・高山純一：リンクフローによる OD 交通量推 計モデル，第 18 回土木計画学講習会テキスト，pp. 97〜 118, 1987.

11）高山純一：リンクフロー観測值に基づいた道路網交通需 要分析モデルに関する方法論的研究, 京都大学学位論文, 1988.

12) Cascetta, E. and Nguyen, S. : A unified framework for estimating or updating origin/destination matrices from traffic counts, Transpn. Res. 22B, pp.437 455, 1988.

13) Bell, M.G.H. : Variance and covariance for origindestination flows when estimated by log-linear models, Transpn. Res. 18B, pp.497 507, 1984.

14）楊 海・飯田恭敬・佐佐木綱：観測リンク交通量に基つ $<\mathrm{OD}$ 交通量推計の信頼度評価法, 土木学会諭文集, No. 419/IV-13, pp. 87 94, 1990.

15) Van Zuylen, J.H. and Branston, D.M. : Consistent link flow estimation from counts, Transpn. Res. 14B, pp.281 293, 1982.

16) Nguyen, S. : Estimating an OD matrix from network data : A network equilibrium approach, Publication 87, Center de recher che sur les Transports, Universite de Montreal, 1977.

17) Gur, Y.J. et al. : Estimation of an origin-destination trip table based on observed link volumes and turning movement volume : technical report. Dep. Transpn., Washington, D.C., 1980.

18）楊 海・佐佐木綱：ネットワーク均衡に基づく観測リン クフローからの OD 交通量推計法に関する検討, 土木計 画学研究・論文集, No. 9, pp. 29 36, 1991.

19) Fisk, C.S. : On combining maximum entropy trip matrix estimation with user optimal assignment Transpn. Res. 22B, pp.66 79, 1988.

20) Fisk, C.S. : Trip matrix estimation from link traffic counts : The congested network case. Transpn. Res. 23B, pp.331 356, 1989.

21）井上博司：シャドウ・コスト概念による観測交通量から の OD 交通量の推計, 土木学会論文集, No. $401 / \mathrm{N}-10$, pp. $41 \sim 50,1989$.

22）高山純一・飯田恭敬：周期変動を考慮した実測交通量に 上る交通需要推計法, 土木計画学研究・論文集, No. 1 , pp. 43〜 50, 1984.

23) Sheffi, Y. : Urban transportation networks : equilibrium analysis with mathematical programming methods, Prentice-Hall, Englewood Cliffs, N.J., 1985.

24) Bard, J.F. : Convex two-level optimization, Mathematical Programming 40, pp.15 27, 1988.

25) Brenninger-Gothe M. Jornsten K.O. and Lundgren J.T. : Estimation of origin-destination matrices from traffic counts using multi-objective programming formulations, Transpn. Res. 23B, pp.257 269, 1989. 
26）高山純一・飯田恭敬・小林光二：リンク観測交通量に基 づく各種 OD 推計法のモデル構造比較, 土木学会第 42 回 年次学術講演会講演概要集, No. 4, pp. 128 129, 1987.

27) Iida, Y., Hasegawa, T., Asakura, Y. and Shao, C.F. : A formulation of on-ramp traffic control system with route guidance for urban expressway, IFAC control in Transportation Systems, pp.229 236, 1989.

28) Marcotte, P. : Network design problem with congestion effects : A case of bilevel programming, Mathematical Programming, 34, pp.142 146, 1986.

29）佐佐木綱・朝倉康夫：OD 需要の変動を内生化した最適 道路網計画モデル，土木学会論文集，No. 383/N -7, pp. 93 102, 1987.

30) Asakura, Y. and Sasaki, T. : Formulation and feasibility test of optimal road network design model with endogenously travel demand, Proc. of the 5th WCTR, pp.351 365, 1990.

31) Suh, S., Park, C.H. and Kim, T.J. : A highway capacity function in Korea : Measurement and calibration, Transpn. Res. 24A, pp.177 186, 1990.

32) Fisk, C.S. : Game theory and transportation systems modeling, Transpn. Res. 18B, pp.301 313, 1984.

33) Hall, M.D. et al. : SATURN ; A simulation assignment model for the evaluation of traffic management schemes, Traffic Eng. \& Control 21, pp.168 176, 1980.
34) Friesz, T.L. and Harker, P.T. : Properties of the iterative optimization-equilibrium algorithm, Civ. Eng. Sys., Vo.2. pp.142 154, 1985.

35) Tobin, R.L. and Friesz, T.L. : Sensitivity analysis for equilibrium network flows, Transpn. Sci., Vol.22, pp.242 $\sim 250,1988$.

36）志水清孝：多目的と競争の理論, 共立出版, pp. 210 215, 1982.

37) Erlander, S., Nguyen, S. and Stewart, F. : On the calibration of the combined distribution-assignment Model, Transp. Res. 13B, pp.259 267, 1979.

38) Fisk, C.S. and Boyce, D.E. : A note on trip matrix estimation from link traffic count data, Transpn. Res. 17B, pp.245 250, 1983.

39）河上省吾 - 広畠康裕・陸化普：複数交通手段を考虑した 観測リンク交通量に基づく OD 交通量推定法，土木計画 学研究・論文集, No. 8, pp. 57 64, 1990.

40）赤松隆・高木淳：観測リンク交通量からのネットワーク 均衡コスト推定法, 土木計画学研究・講演集, No.12, pp. $527 \sim 534,1989$.

41) Dafermos, S. and Nagurney, A. : Sensitivity analysis for the asymmetric network equilibrium problem, Mathematical Programming 28, pp.174 184, 1984.

(1991.2.20受付)

\section{A BILEVEL PROGRAMMING MODEL FOR ESTIMATING ORIGIN-DESTINATION MATRICES FROM TRAFFIC COUNTS WITH CONGESTION EFFECTS

\author{
Hai YANG, Yasuo ASAKURA, Yasunori IIDA and Tsuna SASAKI
}

Conventional methods for estimating origin-destination (O-D) trip matrices from link traffic counts assume that route choice proportions are given constants. In a network with realistic congestion levels, this assumption does not hold. This paper shows how the existing methods such as generalized least squares technique can be integrated with user equilibrium assignment in the form of a convex bilevel optimization problem. The existence of measurement errors and time variations in the observed link flows are explicitly taken into account. The feasibility of the model is always guaranteed without requirement of data preprocessing. A heuristic solution algorithm is presented and illustrated with a numerical example. 